\title{
QUEEN'S
UNIVERSITY
BELFAST
}

\section{Capital Structure Volatility in Europe}

Campbell, G., \& Rogers, M. (2018). Capital Structure Volatility in Europe. International Review of Financial Analysis, 55, 128-139. https://doi.org/10.1016/j.irfa.2017.11.008

\section{Published in:}

International Review of Financial Analysis

\section{Document Version:}

Peer reviewed version

\section{Queen's University Belfast - Research Portal:}

Link to publication record in Queen's University Belfast Research Portal

\section{Publisher rights}

(c) 2017 Elsevier Inc. All rights reserved.

This manuscript version is made available under the CC-BY-NC-ND 4.0 license http://creativecommons.org/licenses/by-nc-nd/4.0/,which permits distribution and reproduction for noncommercial purposes, provided the author and source are cited.

\section{General rights}

Copyright for the publications made accessible via the Queen's University Belfast Research Portal is retained by the author(s) and / or other copyright owners and it is a condition of accessing these publications that users recognise and abide by the legal requirements associated with these rights.

\section{Take down policy}

The Research Portal is Queen's institutional repository that provides access to Queen's research output. Every effort has been made to ensure that content in the Research Portal does not infringe any person's rights, or applicable UK laws. If you discover content in the Research Portal that you believe breaches copyright or violates any law, please contact openaccess@qub.ac.uk. 


\title{
Capital Structure Volatility in Europe
}

\author{
Gareth Campbell $^{1}$ and Meeghan Rogers ${ }^{2}$
}

\begin{abstract}
Contrary to the predictions of the trade-off theory, we find that many companies in Europe had substantial variation in their capital structures between 2006 and 2016 . We show that this pattern occurred across countries. Companies with the most volatile debt ratios tended to be smaller, and were less profitable. Their high debt volatility was partly due to high volatility in operating and investing activities, and partly due to a reduced propensity to let cash balances and equity payouts absorb the fluctuations.
\end{abstract}

${ }^{1}$ Queen's Management School, Riddel Hall, Queen's University Belfast, Belfast, BT9 5EE, gareth.campbell@qub.ac.uk

2 Department of Business Management, School of Business, Farmingdale State College, rogersm@,farmingdale.edu 


\section{Introduction}

According to the static trade-off theory, companies should have a target leverage ratio which balances the benefits and costs of debt. This would imply that firms should try to maintain a particular capital structure, and not deviate much from that level. However, recent research has found that many companies do not seem to pursue this approach. DeAngelo and Roll (2015) have opened a new direction in capital structure research, with their focus on the volatility of debt ratios over time, rather than on their levels. They have found that, in the United States, capital structure stability is the exception, not the rule.

We begin by extending their analysis to Europe, focusing on the period from 2006 to 2016. We examine companies based in the major markets of UK, Germany and France, and also include companies from the PIIGS (Portugal, Italy, Ireland, Greece and Spain) whose capital structures could potentially have been heavily affected by the Credit Crunch and Eurozone Crisis.

We show that, although average debt ratios within countries generally did not change much, there were many companies which experienced substantial changes in their capital structure. We analyse what types of companies experienced the largest changes in debt levels, and which had the highest volatility. We find that small firms, and those with lower returns on assets, experienced the most volatility.

The focus of DeAngelo and Roll (2015) is to demonstrate the surprising amount of debt instability, so they do not extensively examine the causes of this volatility. However, they do speculate that it might be related to the budget constraint. The concept of the budget constraint, whereby a firm's uses of funds must equal its sources of funds, has been discussed at least as far back as Miller and Modigliani (1961), and has also been used more recently by Fama and French (2012), and Gatchev, Pulvino, and Tarhan (2010) in their explanations of why different corporate finance policies may interact. Lambrecht and Myers (2012) also use it to suggest that 
if firms want to choose their level of capital expenditure and dividends, then they must allow debt to fluctuate as a residual.

We build on this research to introduce the concept of the Corporate Finance Trilemma. A trilemma occurs when it is not possible to choose all policies simultaneously, and has been applied in the context of international finance by Mundell (1963) and Fleming (1962). The Corporate Finance Trilemma arises because companies would like to choose their debt, cash holdings, and equity payout policies simultaneously, but they cannot. The primary source of value for a firm comes from Cash from Operating and Investing activities (CFOI). Nevertheless, companies also pay attention to other aspects of their financial situation, and would ideally like to be able to select optimal policies in all of these areas. However, there exists a cash-flow constraint which means that debt flows, changes in cash holdings, and equity payouts must sum to CFOI. The consequence of this is that companies cannot choose their optimal level of debt without it affecting other policies.

We use the cash flow constraint to explain why some companies have reduced their debt, whilst others have increased it. We find that there is little difference between these companies in terms of cash from operations, dividends, equity issues or repurchases, but substantial differences in terms of investments. Firms which have reduced their debt tended to have low investments, whilst those which increased their debt most had much higher investments.

We show that there is a wide distribution in how much volatility different companies allow in their debt flows. We demonstrate that the volatility of debt flows is partly determined by circumstance. Firms with low volatility in debt tend to also have relatively low volatility in most of the other cash flow components. However, debt volatility is also heavily influenced by the choices of the firm. Some companies prioritise debt stability, and do not allow debt to fluctuate in response to changes in CFOI. We show that the beta of debt to CFOI is almost zero 
for companies with the lowest volatility. This means that equity payouts and changes in cash balances must respond to these fluctuations. Other companies give precedence to managing cash holdings and equity payouts, but this means that debt must absorb any changes, making it more volatile. Firms with a high debt volatility have a beta of debt to CFOI which is significantly higher, whilst their beta of equity payouts to CFOI, and changes in cash balances to CFOI, are significantly lower.

This paper makes a substantial contribution beyond the existing research in this area. It moves beyond DeAngelo and Roll (2015) in several ways. Firstly, we consider Europe, and show that many companies changed their capital structures considerably, and that high debt volatility is common outside of the United States. Secondly, we explain why this occurred. We show that it arises because these companies have high cash flow volatility and because the companies have refused to let cash balances and equity payouts fluctuate enough to absorb this volatility. Thirdly, in contrast to DeAngelo and Roll (2015), we also emphasise that many other companies have very stable debt levels. We demonstrate that this is a result of low operating cash flow volatility and because the companies have allowed cash balances and equity payouts to absorb any volatility that does exist.

Several other papers have noted that a budget constraint implies that there will be interaction between different corporate finance policies (Miller and Modigliani, 1961, Fama and French, 2012, Gatchev, Pulvino, and Tarhan, 2010). Lambrecht and Myers (2012) use it to suggest that debt is likely to be treated as a residual. However, we move beyond this in several important ways. Firstly, we argue that for many companies it is actually debt which is kept stable, whilst other components are forced to act as the residual. This adjustment to the model makes it much more flexible in terms of explaining the spectrum of firm behaviour. Secondly, we develop a model in terms of variances and covariances, rather than levels, which provides a much greater insight into the interactions between the components of the budget constraint, 
and allows the model to be analysed empirically. Thirdly, we test our model empirically and obtain novel results. We find that it is both operating and investing cash flow volatility and the response of firms which matter for debt volatility. We also find that it is smaller and riskier firms which are more likely to have higher debt volatility.

This paper also helps to place the enduring debate about the static trade-off and pecking order theories within a broader framework. A large volume of research has found support for and against each theory. For example, Fama and French (2012) suggest that there is a target debt level but the movement towards it is sluggish. Lemmon, Roberts, and Zender (2008) also argue that there are target leverage levels, as firms remained in similar bands of debt over two decades, whilst Byoun (2008) finds that target debt levels are present and that firms move towards this during times of a surplus or deficit. However, DeAngelo and Roll (2015) find little evidence of a target debt level. Previously, Graham and Harvey (2001) have also noted that only $10 \%$ of firms reported that they tried to maintain a very strict target ratio. De Jong et al. (2011) find that firms seem to use the pecking-order theory when they need to raise capital, but follow the trade-off theory when they reduce capital. They state that firms will issue debt to increase their leverage but when considering repurchase decisions, firms will repurchase equity.

The variation in the literature suggests that there are some cases where there is a target debt level, and others where there is not. Fama and French (2005) note that both the trade-off and pecking order theories have serious problems, and put forth the idea that they could be complements to each other instead of two stand-alone theories. This paper concurs with this suggestion. It argues that some firms do maintain stable capital structures, possibly motivated by the trade-off approach. Other firms use debt extensively, possibly motivated by the pecking order theory cautioning against issuing external equity. However, these individual theories need to be combined into a much broader framework, to understand that the capital structure 
of a firm will also be considerably affected by the volatility of its CFOI, and its optimal policies on cash balances and equity payouts.

\section{Data and Instability Results}

We collected firm-specific data from Bloomberg for companies domiciled in the UK, Germany, France and the PIIGS, between 2006 and 2016. We include all companies which had cash flow information available for each year of the sample period but, as is common in capital structure studies, financial firms were excluded. All variables from the cash-flow statement were included for each company for each year, and were scaled by total assets. The analysis focuses on the change and volatility of these variables over this period, so only those companies which had this data for the full sample period were included. The final sample consists of 1,422 companies.

Table 1 shows the average total debt to assets ratio, for each year, for each country. The UK stays generally around $16-17 \%$ for most of the sample but has an increase around the financial crisis. Similarly, France remains around 21\%, with a small increase in 2008 to $23.4 \%$. The results are similar for most of the countries in the sample, with a somewhat constant debt ratio with a small spike around the financial crisis. However, Greece's total debt to assets ratio increases throughout the years of our sample from $30.9 \%$ in 2006 to $42.6 \%$ in 2016 . Spain increases from 2006 until 2014 and then begins to fall.

\section{$<<$ INSERT TABLE $1>>$}

Some examples of volatility in the capital structures of individual companies can be seen from Figure 1, which plots the total debt to assets ratios of two sample companies. For Danone, the total debt to assets ratio rises, falls, then fluctuates somewhat for a few years, another sharp increase. For ITV the debt ratio rises, falls and then rises again. 
$<<$ INSERT FIGURE $1>>$

To assess the extent to which capital structures change, a methodology is used which is based on the approach of DeAngelo and Roll (2015), who analyse firms only from the United States. The capital structure of a company in the first year, 2006, is regressed against the capital structure of that company in year $\mathrm{t}+\mathrm{n}$. This gives an insight into how well values of the debt/asset ratio can explain future values. An $\mathrm{R}^{2}$ close to 1.0 would imply stable capital structures, with those companies with high debt at time $t$, also having high debt at $t+n$. The lower the $\mathrm{R}^{2}$ the lower the stability of capital structures.

Figure 2 illustrates the $\mathrm{R}^{2}$ from these regressions for our sample, using various values of $\mathrm{n}$. Our results are similar to DeAngelo and Roll (2015). The average $\mathrm{R}^{2}$ for year over year cross sections of debt after one year is around 0.70 , implying high but not perfect stability in the short-term. However, the $\mathrm{R}^{2}$ declines considerably as the time between $\mathrm{t}$ and $\mathrm{t}+\mathrm{n}$ increases. A regression using the debt/asset ratios at time $t$ to explain them at time $t+10$ has an $R^{2}$ of just 0.22. This implies that over the longer term, there is substantial variation in the capital structures of many companies.

\section{$<<$ INSERT FIGURE $2>>$}

In Table 2, companies are categorised according to their debt levels. The categories of companies in the first year, 2006, and the final year, 2016, are reported. There does appear to be some stability, particularly amongst companies which started with zero debt with just under half also having zero debt at the end of the sample period. However, the main picture is one of considerable changes. For those companies with $0.1 \%$ to $9.9 \%$ debt/assets at the start of the period, only $35 \%$ remain within this band at the end of the period. Companies which start with higher debt levels are generally unlikely to be within the same band after 10 years. 
It is possible that total changes in capital structures do not reflect volatility, so we go on to distinguish between total changes in debt and the standard deviation of annual debt changes. The latter can provide additional insights into a company's debt policy. Firms with low debt volatility, regardless of whether debt is rising or falling, may be pursuing a deliberate policy. However, firms with high debt volatility are more likely to be viewing debt as a residual, filling in gaps when needed. In Table 3, we show that companies with moderate debt changes overall also tend to have the lowest debt volatility, whilst companies with the largest reductions and increases are more likely to have the highest debt volatility. However, the relationship is not always clear, with some companies which change debt doing it with low volatility, and some of those which keep it steady overall actually have high volatility.

\section{$<<$ INSERT TABLE $3>>$}

This section has established that there is a wide spectrum of capital structure volatility within Europe. Whilst some companies do maintain very stable debt levels, others exhibit very substantial variations across time.

\section{Which Companies have Volatile Capital Structures?}

In this section we analyse which companies have changed their capital structures most. We begin by considering the differences amongst countries in the data sample. DeAngelo and Roll (2015) focused on the United States, and found considerable volatility. By expanding the sample to Europe, it can be seen that volatility is also prevalent in many other countries, as shown in Table 4. Panel A shows that companies in the UK, France and Germany, have a wide distribution in terms of overall changes in capital structure between 2006 and 2016. For example, $13.2 \%$ of firms in the UK reduced their debt/asset ratios by more than 15 percentage 
points, whilst $16.6 \%$ of firms increased them by more than 15 percentage points. Similar trends can be seen across most countries, with some companies increasing and others decreasing their debts. Greece has relatively more companies which substantially increased their debt ratios, whilst Ireland and Portugal have more companies which reduced their debt ratios. This suggests very different experiences within the PIIGS.

In terms of volatility, shown in Panel B, there also appears to be wide distributions, with each country having many companies which had very low volatility in their debts, whilst also having many companies which had very high volatility. Companies in France tended to be relatively less volatile, whilst companies in Spain and Ireland tended to be more volatile. Although Greece had many companies which increased their debts in absolute terms, this seems to have often occurred gradually, as they did not have particularly high volatility.

$$
<<\text { INSERT TABLE } 4>>
$$

It is also possible that characteristics of particular firms will play a role in capital structure volatility. In Table 5, the means of firm-specific variables are shown for different groups, according to the overall changes in their debt/assets ratio in Panel A, and according to their volatility in Panel B. We include the average total assets of the firm during the period between 2006 and 2016. Based on this, we also create a Small Size dummy variable, in line with Leary (2009) which equals 1 for those companies in the lowest two deciles according to the size of their assets. This aims to capture the difficulties which the smallest firms may have in accessing debt.

We also include a variable for the change in assets between 2006 and 2016, to examine which companies were growing their asset base most. We also include a variable for average revenue growth during this period. The Return on Assets is the average profits/assets ratio 
during the same period. We also include dummy variables for industries based on their ICB classification.

$$
<<\text { INSERT TABLE } 5>>
$$

From Table 5, we can see that firms which reduced their debt most, or increased it most, tended to be smaller in terms of total assets than companies which did not change much overall. Related to this, we see that larger firms tend to also have the lowest volatility in their debt/assets ratio. This is consistent with DeAngelo and Roll (2015) and Graham and Harvey (2001) who find that debt stability is most frequent in large companies. However, notably, the dummy variable for the smallest $20 \%$ of companies does not appear to be significantly different, suggesting that this is not being driven by constraints on very small companies being able to raise debt.

Companies which had the largest increases in debt, and the most volatile debt, also tended to have a greater change in assets during this period. They were also much less profitable, with the average return on assets actually being negative. Return on assets decreases from $2.42 \%$ in the Lowest volatility quintile to $-1.00 \%$ in the Highest volatility quintile, suggesting that companies with strict debt are more profitable than those with volatile debt. Revenue growth also increases as debt volatility increases, moving from $9.75 \%$ in the first quintile to $22.58 \%$ in the fifth quintile.

Tables 6 and 7 perform regressions using these variables to analyse which companies had the largest changes in debt, and the most capital structure volatility. There have been numerous studies of how such factors may affect the levels of corporate leverage, such as Gungoraydinoglu and Oztekin (2011), but this is the first to establish the determinants of volatility in capital structures.

$<<$ INSERT TABLES 6 and $7>>$ 
Similar patterns are seen within the multivariate regressions as has been discussed based on sorts of the data. Companies with higher profitability, as measured by their Return on Assets, tended to reduce their debts, as shown in Table 6, and had lower volatility in their debts, as shown in Table 7.

Size is not a predictor of overall changes in debt, but is a highly significant predictor of debt volatility. The smallest $20 \%$ of companies had significantly higher debt volatility, whilst companies with the largest assets had significantly lower volatility. When entering both together in a regression, the total assets remains significant. When controlling for other factors, it can be seen that companies with the largest increases in assets also had the most debt volatility. Utilities and French companies tended to have lower volatility. A dummy variable bringing together the PIIGS is not significant, reflecting the differences between companies within this group.

This section has analysed which types of companies experience capital structure volatility. It has found that different characteristics of the firm, such as smaller size, and low return on assets are associated with lower debt volatility.

The next question that arises is how these changes in debt were implemented, as they could arise either from changes in debt, or equity, or other liabilities. Furthermore, the changes in debt can be broken down into debt flows, which are reported on the cash flow statement, and those which are only reported on the balance sheet. Fama and French (2005) have noted that changes in the balance sheet values of equity often do not correspond to the amount of equity which has been issued and repurchased as reported in the cash flow statement, with mergers and acquisitions being the most important cause of the discrepancy between the two statements. A similar discrepancy can arise in a reporting of debt changes.

Table 8 decomposes the origins of assets in 2016 into whether they arose from the values of debt, equity and other liabilities in 2006 , or changes in these components between 
2006 and 2016. This is achieved by taking the absolute values of debt, equity and other liabilities in 2006 and scaling them by the total assets of the company in 2016 . The changes in the absolute value of debt, equity and other liabilities between 2006 and 2016 were also calculated, and scaled by the total assets of the company in 2016. The sum of debt cash flows between 2006 and 2016 was obtained from the cash flow statement. The change in balance sheet only debt was then calculated as the total change in debt minus the sum of debt cash flows. These components were then also scaled by total assets in 2016 .

Companies were then split into categories based on how much their debt/assets ratio changed during the sample period. It can be seen from Table 8, that the companies with the largest reductions in their debt/assets ratio started with a relatively high amount of debt, but then reduced this debt over time, both in terms of balance sheet only debt and debt cash flows. At the same time, the value of equity rose. These two factors combined led to substantial reductions in their debt/assets ratio. The reverse is true for companies with large increases in their debt/assets ratio.

The various components can be combined to analyse the starting debt ratios, the final debt ratios, and then a theoretical calculation of what the final debt ratio would have been if there had been zero debt flows. Table 8 suggests that the group with the largest reduction in their leverage would have reduced their debt/assets ratio from $42.9 \%$ to $29.1 \%$, just from changes in equity and balance sheet only debt. However, debt cash flows were also important, and reduced the final debt/assets ratio to an average of $15.4 \%$. This suggests that changes in capital structure were driven by a range of factors, but that companies repaid a substantial amount of debt as part of this.

\section{$<<$ INSERT TABLE $8>>$}

The reverse pattern emerges for companies which substantially increased their leverage. They would have increased their debt/assets ratios anyway, from $15.7 \%$ to $31.2 \%$, 
due to just changes in equity and other liabilities, but debt cash flows played a major role as well, raising the debt/assets ratio further to $47.5 \%$. Changes in capital structure were therefore driven by several other changes, but debt flows played a central role. In the next sections we will analyse these debt flows in more detail, the different sources and uses of funds within a company, and how this is connected with the use of debt.

\section{Debt Flows}

Most literature on capital structure policy focuses solely on debt, and target debt levels. However, Gatchev, Pulvino, and Tarhan (2010) point out that it is not possible to look at only one corporate finance policy without looking at the others. Aggarwal and Kyaw (2010) stress the importance of considering the interdependence of capital structure and dividend policy in their study of the impact of multinationality on debt levels. Lambrecht and Myers (2012) state that companies are likely to have a policy on their investment, and once this is fixed any fluctuations would have to be absorbed by dividends or debt. Due to the risk-averse nature of managers and habit formation, companies will try to smooth dividends, so the only remaining variable to change is debt. They propose this as a general theory, implying that it explains the behaviour of most companies. However, in this research we find that different companies pursue different approaches. There are cases where debt is kept stable, but in others they are allowed to vary substantially.

The sources and uses of cash can be seen from cash flow statements. These are split into activities involving operations, investing and financing. Operations involve cash earned by the company through its business dealings. Investment can involve capital expenditure, acquisitions, and other short-term and long-term investments. Financing involves flows to and from shareholders in terms of dividends, share repurchases and issues, and debt flows. 
In Table 9 we breakdown how each component of the cash flow statement changed, when companies are split according to their average debt flows during this period. Cash from Operations does not seem to vary much between those companies with the largest debt outflows, and those with the largest debt inflows. The investing activities are split into three types, and in each of these the companies which raised the most debt were those which had spent most on investments. Those companies with the largest debt inflows spent an average of $2.4 \%$ of assets, per year, more on fixed and intangible assets, $0.6 \%$ more on acquisitions, and $2.2 \%$ more on other investments, than those companies with the largest debt outflows. Put together, the Cash from Operating and Investing Activities was positive for those companies with the most debt outflows, and negative for companies with the most debt inflows, producing a significant difference of $5.3 \%$ of assets per year between these groups.

$$
<<\text { INSERT TABLE } 9>>
$$

Companies which raised the most debt also increased their cash balances more, by $0.6 \%$ of assets per year more than those which paid off their debts. They also tended to payout more in terms of dividends and equity repurchases. These companies did raise more from equity issues, but it was not close to being enough to cover the additional cash outflows which they had.

Table 9 groups together several components to highlight the main drivers of debt flows. The Cash from Operating and Investing Activities is the amount of cash left from the main value creating decisions of the company. This will then be used to change cash holdings, make equity payouts, or for debt flows. This equation can be written as in Equation 1.

$$
\mathrm{CFOI}+\mathrm{dCash}+\text { EqPay }+\mathrm{dDebt}=0
$$


Where:

CFOI $=$ Cash from Operating and Investing Activities

EqPay = Dividends + Equity Repurchases + Equity Issues + Other Finance

$\mathrm{dCash}=$ Change in Cash Balances

$\mathrm{dDebt} \quad=$ Debt Flows

A company cannot choose their desired level for each component of equity payouts, changes in cash holdings, and debt flows, as there would be no balancing variable to adjust the equation to follow CFOI. To focus on more detail on debt, we can re-arrange the equation to become:

$$
\mathrm{CFOI}+\mathrm{dCash}+\text { EqPay }=-\mathrm{dDebt}
$$

From Table 9 we can see that differences in debt flows originates mainly from differences in CFOI (5.3\%), but is exacerbated by changes in cash balances $(0.6 \%)$, with differences in equity payouts having almost no impact $(0.1 \%)$. Given the cash flow constraint, this gap had to be filled by changes in debt. Companies which had run up a large deficit had to borrow to cover it, whilst those which ran a surplus used it to pay off debts. The difference in debt flows between those which had the largest debt inflows, and those which had the largest debt outflows, was $5.9 \%$ of assets per year.

Examining average changes in each cash flow component can show how the policies are interlinked. However, it is not clear from such an approach which components are being chosen, and which are treated as a residual. Focusing on the volatility of each component, and its co-movement with other components, may help to provide more insights. Policies which are deliberately chosen are more likely to have low volatility, and be unresponsive to CFOI. In contrast, when a component is a residual it is likely to have higher volatility, and move to absorb changes in CFOI. 
If an optimal debt policy is being pursued then debt flows would likely have low volatility, and would not fluctuate just because of changes in CFOI. In contrast, if debt is treated as a residual then it is likely to have high volatility, and co-move with CFOI to absorb fluctuations. To analyse the instability of debt flows we can take the cash flow constraint described in Equation 2, and use the rules of variances to show that:

$$
\begin{aligned}
\operatorname{var}(\mathrm{dDebt})= & \operatorname{var}(\mathrm{CFOI})+\operatorname{var}(\mathrm{dCash})+\operatorname{var}(\text { EqPay }) \\
& +2 \operatorname{cov}(\mathrm{CFOI}, \mathrm{dCash})+2 \operatorname{cov}(\mathrm{CFOI}, \text { EqPay })+2 \operatorname{cov}(\mathrm{dCash}, \text { EqPay })
\end{aligned}
$$

Equation 3 shows that the variance of a company's debt flows depends on the variance of CFOI, changes in cash holdings and equity payouts, and the covariance between these components. If cash balances are increased (seen as an outflow of cash to reserves), when CFOI inflows increase, this will absorb some of the volatility, and reduce the variance of debt flows. Similarly, if equity payouts increase (seen as outflow of cash to shareholders) when CFOI inflows increase, this will also reduce the variance of debt flows. If there is a negative covariance between changes in cash holdings and equity payouts, meaning that when one increases the other decreases, this would also tend to reduce the variance of debt flows.

The variance of debt flows will therefore depend on the variance of other components, and how these other components interact. As the components are connected, it is not possible for each policy to be chosen, as at least one must be left to fluctuate to absorb other changes. If a company wants to choose equity payouts and cash holdings, rather than just let them fluctuate with CFOI, then this will tend to increase debt volatility. If the company wants to choose a particular amount of debt and cash holdings, then equity payouts must fluctuate. If the company chooses debt and equity payouts, then it is cash holdings which must fluctuate. 
We refer to this situation as the Corporate Finance Trilemma. If a company maintains a strict policy on debt, then some other components must become relatively more volatile. If a company has a strict policy regarding the other components of the cash flow statement, equity payouts and changes in cash holdings, then debt will act as the balancing variable that will increase or decrease according to the changes in CFOI. Companies would like to choose each policy, but they cannot maintain all policies simultaneously.

There are a number of reasons why companies would want to choose policies for each of the variables. It should be noted throughout this discussion that companies which have zero dividends, zero repurchases, zero issues or zero debt are still choosing to keep these components fixed, and are not allowing them to absorb any of the fluctuations in CFOI or other variables.

Some companies will want to choose an optimal level of cash holdings, rather than simply letting it fluctuate with profits. Companies may not want to build up cash as this would lead to very low, or zero, rates of return (Masulis and Trueman, 1988). Excess cash could also lead to agency problems (Jensen, 1986). Some companies that have built up excessive amounts of cash have been targeted by activist investors, who regard these cash holdings as being inefficient.

Other companies select what they regard as an optimal level of equity payouts, and do not make dividends, share repurchases and equity issues fluctuate exactly with CFOI. Although Miller and Modigiliani (1961) argue that dividends are irrelevant to firm value, Lintner (1956) found that companies generally try to ensure that dividends only change gradually, if at all. Leary and Michaely (2011) state that managers attempt to maintain a stable dividend policy, as it is generally regarded favourably by the market. Certain shareholders in high tax-brackets will want a zero dividend payout to avoid paying more taxes (Copeland et al., 2005). 
If the company relied on repurchases to absorb the changes in CFOI, they would tend to make repurchases in times of good performance. Companies may try to keep repurchases close to zero, as they do not want to have to buy back shares that are overpriced. Another reason to keep repurchases fixed is that it could reduce the asset base of the company which in turn would have a negative effect on bondholders as there is less collateral (Copeland et al., 2005).

Others may want to maintain zero equity issues, based on the pecking order theory. If managers have inside information, and work in the best interests of existing shareholders, they will tend to issue equity only when they believe it is overpriced. As investors are aware of this situation, they may regard an equity issue as a bad signal, meaning that share prices will decline and the equity issue is unsuccessful (Myers and Majluf, 1984).

There are certain companies who will not want to have debt just co-move with profits. Some companies may prefer to maintain what they regard as an optimal debt level, which balances the tax shield (Modigliani and Miller, 1963) against the additional financial distress costs, which gives rise to the static trade-off theory (Kraus and Litzenberger, 1973). In line with static trade-off theory, Bonaime et al. (2014) note that firms will repurchase shares to reach this optimal leverage. Strebulaev and Yang (2013) also show that a substantial number of firms maintain zero debt, whilst Dang (2013) finds that many firms in the UK also maintain zero leverage, either because they are constrained in their ability to raise debt, or because they want to maintain flexibility whereby they could raise debt in future if it was needed for investment.

Although firms would like to choose all policies simultaneously, they cannot due to the Corporate Finance Trilemma. This means that companies cannot maintain their optimal cash, equity payout and debt policies at the same time. At least one must be allowed to fluctuate to absorb changes in CFOI. 
It is also possible that constraints on individual components of the Trilemma, rather than choice, play a role. The most important constraint is likely to be the ability of some firms, possibly smaller firms, to issue new debt or equity. Companies with already high debt may also find it difficult to raise more debt, whilst the other extreme, firms with no debt will not be able to let debt fluctuate downwards. Similarly, companies with zero dividends or repurchases will not be able to cut them any further. Therefore these variables may be set due to either choice or constraint. Regardless of why they remain stable, the consequence remains the same, some other component of the Trilemma must act as the residual and will have to fluctuate more to absorb changes in CFOI.

\section{Corporate Finance Trilemma Results}

In this section we use the Corporate Finance Trilemma to explain why some companies have very high debt volatility, whilst others have very low debt volatility. We argue that the differences between firms depends partly on circumstance, due to the volatility of CFOI, and partly on the choices of the firm as to whether they will allow cash balances and equity payouts to absorb this volatility.

We begin by examining the circumstance of each company. We split companies into five quintiles, depending on the standard deviation of each company's debt flows from 2006 to 2016. Quintile 1 consists of companies with the lowest volatility which show little movement, and Quintile 5 has the highest volatility. We then calculate the average across firms, within each quintile, of the standard deviation of each component of the cash flow statement, as shown in Table 10.

$<<$ INSERT TABLE $10>>$ 
There is a clear indication that companies with higher debt volatility also have higher volatility in most other components. Companies in quintile 5 not only have significantly higher volatility of debt flows, they also have significantly higher volatility in cash from operations, investments in fixed and intangible assets, cash from acquisitions and divestitures, and other investments. The higher debt volatility therefore partly arises from the operating and investment environment of the firm.

However, it should be noted that choice is also important. For example, companies in quintile 1 , which have the lowest debt volatility, actually have much higher volatility in CFOI than quintile 2. Nevertheless, due to the policies of the firms, this volatility gets absorbed by other components of the Trilemma, and debt volatility is kept low.

To analyse the choices of companies, we examine in more detail how different components of the Trilemma respond to CFOI. We run separate regressions examining the relationship between $\mathrm{CFOI}$ and debt flows, CFOI and equity payouts, and CFOI and changes in cash balances, as shown in Table 11. Due to the cash flow constraint the betas from these regressions must sum to 1 , as CFOI must be used in one of these ways. To examine differences between groups, we include a dummy variable for each quintile based on the standard deviation of their debt flows. For example, DummySDDebt5 is a dummy variable for those companies which have the most volatile debt flows, DummySDDebt4 has the next most volatile etc. We then interact these dummies with the CFOI variable. This interaction term will reveal differences between quintiles in terms of how they respond to changes in CFOI. We also include dummy variables for companies based on their size, their debt levels, and whether they paid a dividend or made repurchases in the previous year, as these may constrain their ability to let some variables fluctuate with CFOI.

$<<$ INSERT TABLE $11>>$ 
The results suggest that for the base group, the companies with the lowest debt volatility, there is almost no connection between debt flows and CFOI with a beta of just 0.037 . In contrast the beta of equity payouts and CFOI is 0.517 , and the beta of changes in cash balances and CFOI is 0.446 . This suggests that companies with low debt volatility are choosing to keep debt stable, but this means that equity payouts and cash balances must fluctuate.

The interaction term between CFOI and DummySDDebt2 shows that these companies have a significantly higher beta on the relationship between debt and CFOI, suggesting that debt begins to respond more. This pattern continues for Quintiles 3, 4 and 5, each of which shows a further significant increase on the debt beta. The implied beta between debt and CFOI for Quintile 5 is $0.408(=0.037+0.371)$, showing that debt absorbs much of the changes in CFOI for this group of companies which have high debt volatility.

The opposite pattern emerges with the beta on the relationship between equity payouts and CFOI, and between changes in cash balances and CFOI. These betas are significantly lower for companies with higher debt volatility, showing that as debt becomes more responsive, equity payouts and cash balances become less so.

The results on the dummy variables for possible constraints are also informative. They suggest that the smallest companies, based on the previous year's total assets, actually have lower debt outflows than others, after controlling for CFOI and other variables. This suggests they are not under pressure to pay back debts, and are not heavily constrained in terms of raising debt or rolling over existing debt. Companies which already had high debt levels tend to make higher debt repayments, but lower equity payouts, which could possibly illustrate that they are unable or unwilling to raise more debt. Companies with low debt levels did the reverse, possibly due to the constraint of some of these companies facing a lower bound of zero on their debt levels and not being able to reduce debt further. Companies which did not pay a dividend, 
or make repurchases, in the previous year, tended to have lower equity payouts in the current year, but made higher debt repayments.

The results in this section suggest that the volatility of debt flows partly depends on circumstance, meaning the volatility of other cash flow components as shown in Table 10, and partly on choice, meaning the approach of the company in terms of whether it treats debt as a residual which can be used to absorb changes in CFOI, as shown in Table 11.

To show the sources of debt volatility we report the components of Equation 4, broken down by quintile, in Table 12. Companies with low debt flow variance also tend to have fairly low variance in terms of CFOI $(1.0 \%)$, equity payouts $(0.9 \%)$ and cash holdings $(1.3 \%)$. The covariance between these components is such that it absorbs almost all of the variance that does exist. Cash holdings are most responsive, moving along with CFOI, reducing the variance of debt by $1.4 \%$. Equity payouts also move with CFOI, reducing the variance of debt by a further $0.6 \%$. Cash holdings also moves in the opposite direction to equity payouts, meaning that as one increases, the other decreases, and debt flows are not needed to fund both of them simultaneously, reducing the variance of debt by another $1.2 \%$. Put together, this can explain why these firms have such a low variance of debt flows, at $0.0 \%$ to one decimal place.

$$
<<\text { INSERT TABLE } 12>>
$$

For Quintile 2, it is interesting to note that the variance of CFOI (0.5\%), EqPay $(0.3 \%)$, and dCash $(0.4 \%)$ are much lower. However, the covariances absorb much less, resulting in a higher variance of debt flows. This suggests that these companies have more benign circumstances, but they have not chosen to target debt stability as rigorously as Quintile 1. Similar patterns emerge for Quintiles 3 and 4, which also have low variance in CFOI, EqPay and dCash, but due to their choices in terms of how to absorb this volatility, they end up with higher debt volatility. 
These results stand in contrast to companies with flexible capital structures, who have much more volatile circumstances. Breaking down the variances and covariances in line with Equation 4 again reveals how these factors interact to produce high debt volatility. The variance of CFOI is much higher at $2.2 \%$, and there have also been some increases in the variance of cash holdings to $1.1 \%$, and equity payouts to $1.3 \%$. The covariances between the components show us if they are moving together to absorb this volatility. We can see that the comovement of cash holdings and CFOI are absorbing only $1.1 \%$ of this variance. The covariance of CFOI and equity takes up a further $1.0 \%$, whilst the covariance of cash holdings and equity deals with another $1.0 \%$. The remainder has to be absorbed by debt, and the variance of debt flows for these firms is $1.5 \%$.

A comparison between the High and Low volatility quintiles shows significant differences both in terms of circumstance and choice. Put together, the variances are much higher. Covariances absorb little of the extra volatility, meaning that debt flows must fluctuate considerably to cover the gaps.

In summary, the results above suggest that the Corporate Finance Trilemma can help to explain patterns in debt volatility. Cash from Operating and Investing activities is the main source of value to a company, but the secondary decisions of which variable to act as a residual to these fluctuations must also be considered. Some companies will choose to keep debt stable, but when a company chooses to focus on cash holdings and equity payout policy it leaves little room to also have a strict policy on their debt. The high debt volatility companies are not allowing cash holdings and equity payouts to fluctuate enough in line with CFOI, or each other, so debt flows must act as a residual.

\section{Conclusion}


The empirical results presented in this paper confirm, using data on European companies, that although some firms do maintain strict capital structures, there are many others which allow their capital structures to move substantially over time. Companies with the most volatile debt tend to be smaller and less profitable. The cash flow constraint was used to illustrate that companies which raised debt tended to have been spending much more on investments.

The theory of the Corporate Finance Trilemma, put forward in this paper, argues that due to the cash flow constraint firms cannot choose their ideal policies for equity payouts, cash holdings and debt simultaneously. Some companies will prefer to maintain a stable debt level, but they must then allow some other variables to fluctuate. Other companies may prefer to pursue optimal policies in equity payouts and cash holdings, but they must then accept high volatility in debt.

The concept of the Trilemma was then used to explain why some companies have stable capital structures, whilst others are much more flexible. Firms with strict capital structures generally have low volatility in Cash from Operating and Investing activities, and any variance that does exist is absorbed, by changes in cash holdings and equity payouts, meaning that debt can remain very stable. In contrast, firms with flexible capital structures have high volatility in CFOI which is not absorbed by changes in cash or equity payouts, meaning that debt must act as the residual and become highly volatile.

These results suggest that corporations cannot simply set their capital structures in isolation. Some companies will prioritise stable debt levels, but they must then accept fluctuations in other variables. Other companies will give precedence to equity payouts and cash holdings, and they resolve the Corporate Finance Trilemma by allowing debt to move more flexibly. 


\section{References}

Aggarwal, R. and Kyaw, N.A., 2010. "Capital structure, dividend policy, and multinationality: Theory versus empirical evidence", International Review of Financial Analysis, vol. 19, no. 2, pp.140-150.

Bonaime, Alice Adams, Oztekin, Ozde, and Warr, Richard S. 2014. "Capital Structure, Equity Mispricing, and Stock Repurchases”, Journal of Corporate Finance, vol. 26, pp.182200.

Byoun, Soku. 2008. "How and When do Firms Adjust their Capital Structures Towards Targets?", Journal of Finance, vol. 63, no. 6, pp. 3069-3096.

Copeland, T., Weston, J., and Shastri, K. 2005. Financial Theory and Corporate Policy. Reading, MA: Addison-Wesley.

Dang, V.A., 2013. "An empirical analysis of zero-leverage firms: New evidence from the UK”, International Review of Financial Analysis, vol. 30, pp.189-202.

DeAngelo, H., and Roll, R. 2015. "How Stable are Corporate Capital Structures?", Journal of Finance, vol. 70, no. 1, pp. 373-418.

De Jong, A., Verbeek, and M., Verwijmeren, P. 2011, "Firms' debt-equity decisions when the static tradeoff theory and the pecking order theory disagree", Journal of Banking and Finance, vol. 35, pp.1303-1314.

Fama, Eugene F. and French, Kenneth R. 2005. "Financing Decisions: Who Issues Stock?", Journal of Financial Economics, vol. 76, no. 3, pp. 549-582.

Fama, Eugene F. and French, Kenneth R. 2012. "Capital Structure Choices", Critical Finance Review, vol. 1, no. 1, pp 59-101.

Fleming, J. Marcus. 1962. "Domestic financial policies under fixed and floating exchange rates". IMF Staff Papers.

Gatchev, Vladimir A., Pulvino, Todd and Tarhan, Vefa. 2010. "The Interdependent and Intertemporal Nature of Financial Decisions: An Application to Cash Flow Sensitivities", The Journal of Finance, vol. 65, no.2, pp 725-763.

Gungoraydinoglu, Ali and Oztekin, Ozde, 2011. "Firm- and country-level determinants of corporate leverage: Some new international evidence", Journal of Corporate Finance, vol. 17, no. 5, pp 1457-1474.

Graham, John R. and Harvey, Campbell R. 2001. "The Theory and Practice of Corporate Finance: Evidence from the Field”, Journal of Financial Economics, vol. 60, pp 187- 243.

Jensen, Michael C. 1986. "Agency Costs of Free Cash Flow, Corporate Finance, and Takeovers”, The American Economic Review, vol. 76, no. 2, pp 323-329. 
Kraus, A., and Litzenberger, R. H. 1973. "A State-Preference Model of Optimal Financial Leverage”. The Journal of Finance, vol. 28, no. 4, pp. 911-922.

Lambrecht, Bart M. and Myers, Stewart C. 2012. "A Lintner Model of Payout and Managerial Rents”, The Journal of Finance, vol. 67, no. 5, pp 1761-1810.

Leary, M.T., 2009. "Bank loan supply, lender choice, and corporate capital structure". The Journal of Finance, 64(3), pp.1143-1185.

Leary, Mark and Michaely, Roni. 2011. "Determinants of Dividend Smoothing: Empirical Evidence", The Review of Financial Studies, vol. 24, no. 10, pp 3197-3249.

Lemmon, Michael L., Roberts, Michael R. and Zender, Jaime F. 2008. "Back to the Beginning: Persistence and the Cross-Section of Corporate Capital Structure", The Journal of Finance, vol. 63, no.4, pp 1575- 1608.

Lintner, John. 1956. "Distribution of Incomes of Corporations among Dividends, Retained Earnings, and Taxes”, The American Economic Review, vol. 46, no. 2, pp 97-113.

Masulis, Ronald W. and Trueman, Brett. 1988. "Corporate Investment and Dividend Decisions under Differential Personal Taxation", The Journal of Financial and Quantitative Analysis, vol. 23, no. 4, pp 369-385.

Modigliani, F. and Miller, M.H. 1961. "Dividend Policy, Growth, and the Valuation of Shares", The Journal of Business, vol. 34, no.4, pp 411-433.

Modigliani, F. and Miller, M.H. 1963. "Corporate income taxes and the cost of capital: A correction”, The American Economic Review, vol. 53, no.3, pp 433-443.

Mundell, Robert A. 1963. "Capital mobility and stabilization policy under fixed and flexible exchange rates”. Canadian Journal of Economic and Political Science, vol. 29 , no.4, pp. $475-485$.

Myers, Stewart C. and Majluf Nicholas S., 1984. "Corporate financing and investment decisions when firms have information that investors do not have", Journal of Financial Economics, vol.13, pp 187- 221.

Strebulaev, Ilya A., and Yang, Baozhong, 2013. "The mystery of zero-leverage firms", Journal of Financial Economics, vol. 109, no. 1, pp 1-23. 
Figure 1

Examples of Leverage Ratios: 2006 to 2016

The debt ratio is measured by the total debt to total assets ratio. Data is obtained from Bloomberg.

Panel A: Danone

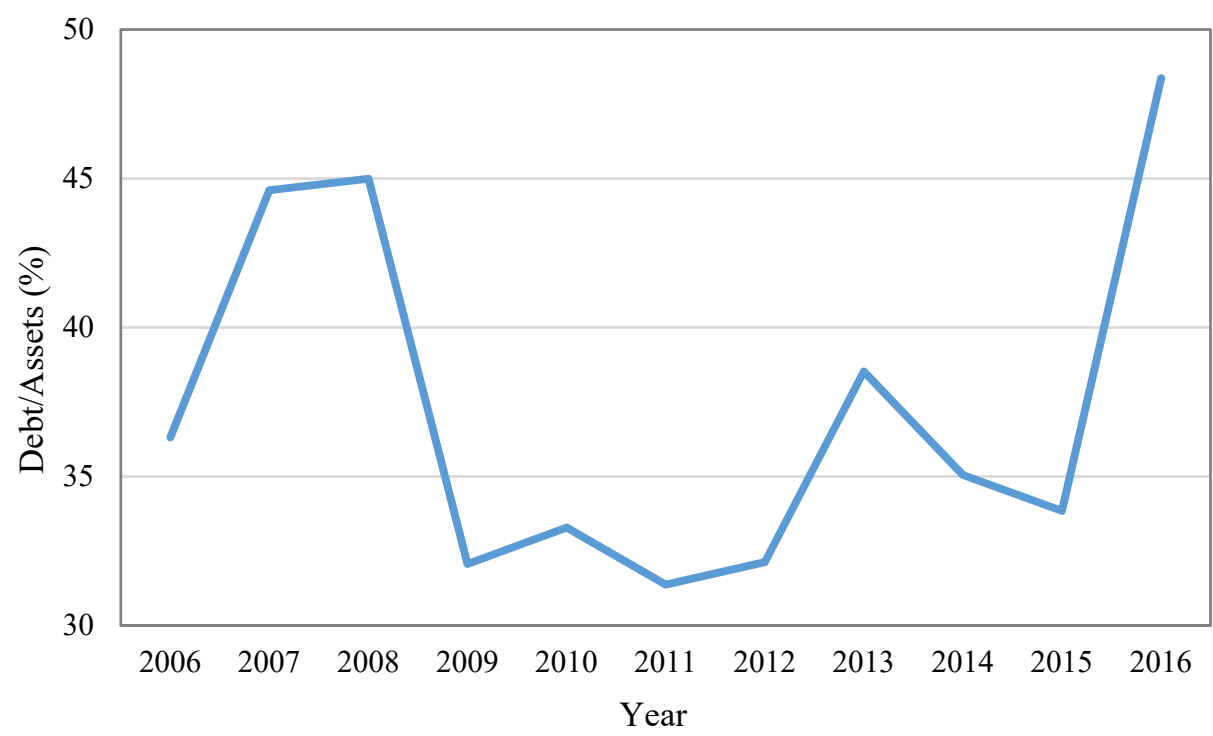

Panel B: ITV

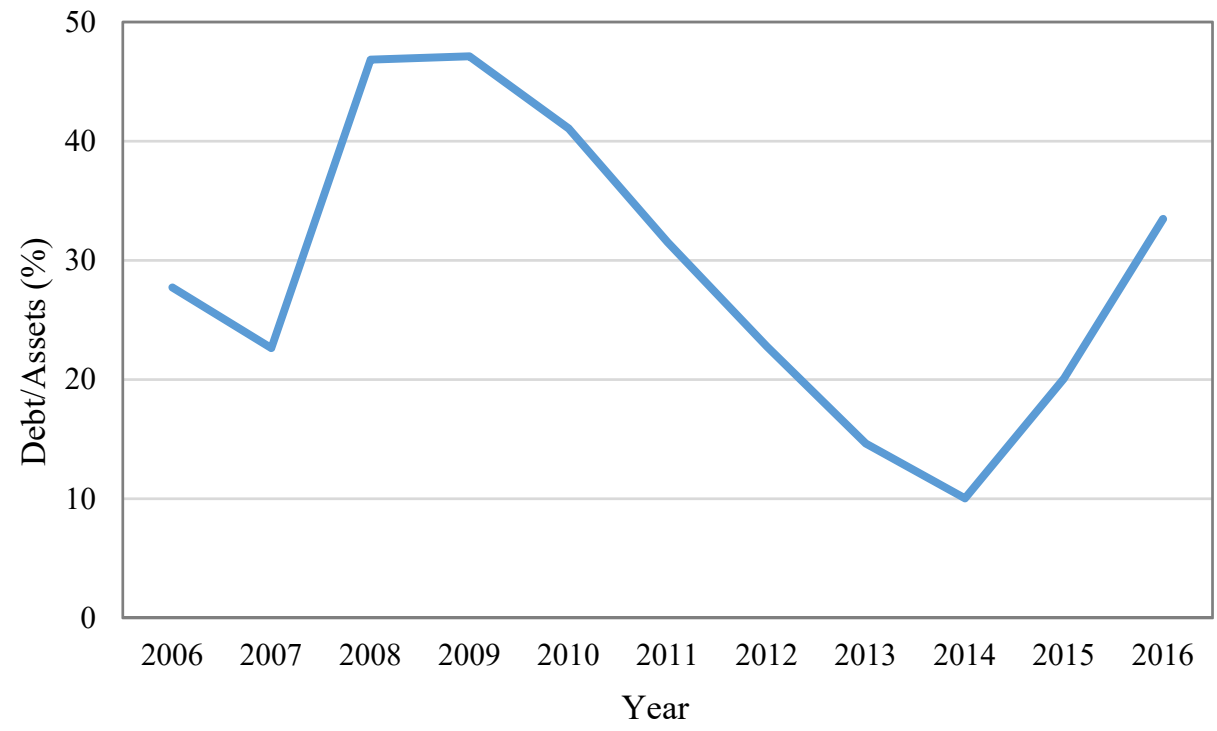


Figure 2

\section{$\mathbf{R}^{2}$ from Regressing Capital Structures in 2006 against Future Years}

The figure shows the $\mathrm{R}^{2}$ from a regression of capital structure in 2006 against capital structure in other years. Capital structure is measured by the total debt to total assets ratio.

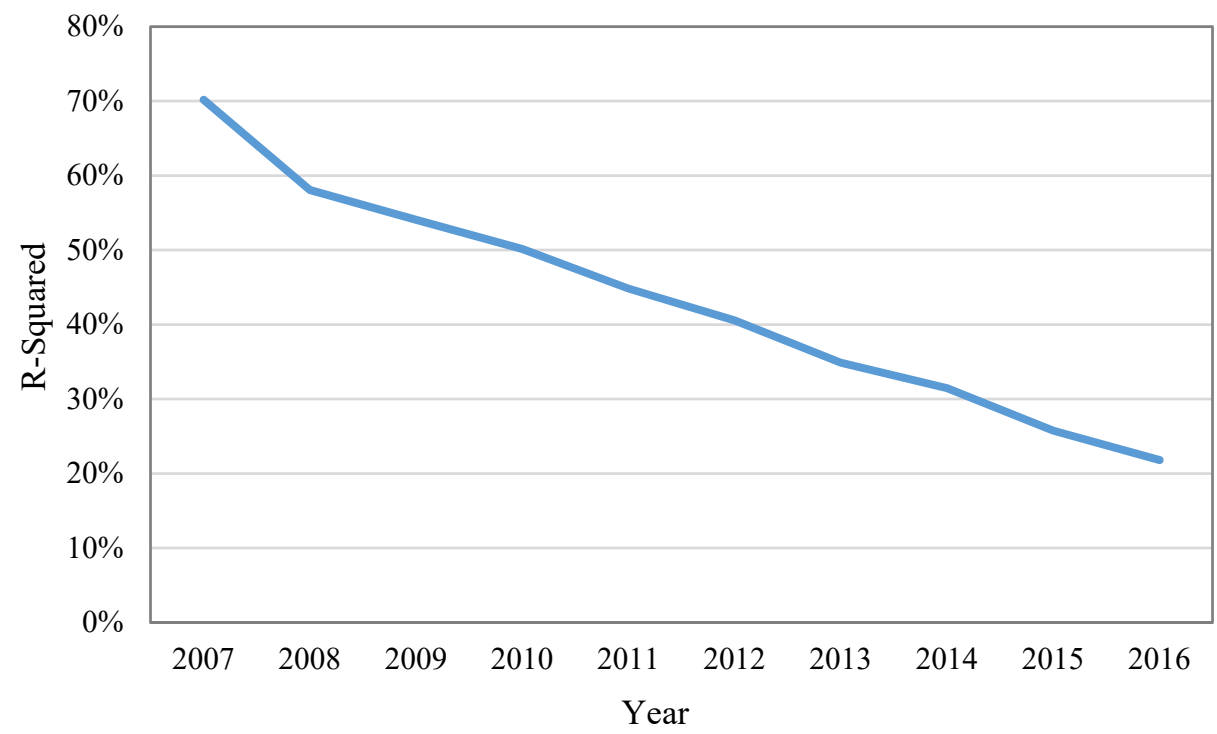


Table 1

Total Debt/Assets Ratio by Country and Year

The debt ratio is measured by the total debt to total assets ratio. The average for each year is given, per year, for each country in the sample.

\begin{tabular}{|c|c|c|c|c|c|c|c|c|c|c|c|c|}
\hline & \multirow[b]{2}{*}{$\begin{array}{c}\text { Companies } \\
\text { per year }\end{array}$} & \multicolumn{11}{|c|}{ Average Total Debt/Assets Ratio } \\
\hline & & 2006 & 2007 & 2008 & 2009 & 2010 & 2011 & 2012 & 2013 & 2014 & 2015 & 2016 \\
\hline UK & 463 & 17.5 & 19.0 & 20.2 & 19.0 & 16.9 & 16.3 & 16.1 & 16.5 & 17.4 & 18.7 & 18.9 \\
\hline France & 296 & 21.1 & 21.6 & 23.4 & 22.5 & 21.1 & 21.0 & 20.9 & 20.6 & 20.9 & 21.5 & 22.2 \\
\hline Germany & 277 & 21.0 & 21.7 & 23.0 & 23.1 & 21.0 & 20.5 & 20.7 & 21.2 & 20.8 & 21.4 & 21.0 \\
\hline Italy & 138 & 24.9 & 25.2 & 27.3 & 28.2 & 28.0 & 29.6 & 29.0 & 29.4 & 28.4 & 28.8 & 28.2 \\
\hline Greece & 119 & 30.9 & 31.9 & 34.9 & 34.6 & 36.2 & 38.1 & 38.8 & 39.5 & 39.7 & 41.7 & 42.6 \\
\hline Spain & 61 & 28.6 & 27.9 & 30.6 & 33.1 & 32.8 & 33.2 & 33.5 & 34.9 & 35.4 & 34.5 & 32.7 \\
\hline Ireland & 38 & 22.9 & 19.5 & 23.0 & 22.8 & 23.0 & 20.3 & 21.3 & 21.4 & 20.1 & 19.5 & 17.4 \\
\hline Portugal & 30 & 39.8 & 39.3 & 43.1 & 43.7 & 41.2 & 43.5 & 44.1 & 37.1 & 39.2 & 38.8 & 37.2 \\
\hline Total & 1422 & 21.9 & 22.5 & 24.4 & 23.9 & 22.6 & 22.6 & 22.6 & 22.8 & 23.0 & 23.8 & 23.8 \\
\hline
\end{tabular}


Table 2

Total Debt/Assets in 2006 and 2016

Companies have been split into categories based on their debt/assets ratio in 2006 . The percentage of companies in each category which had a given debt/assets ratio in 2016 is then shown.

\begin{tabular}{|c|c|c|c|c|c|c|c|c|c|c|}
\hline & & \multicolumn{8}{|c|}{ Debt/Assets in 2016} & \multirow[b]{2}{*}{$\begin{array}{l}\text { Number of } \\
\text { Companies }\end{array}$} \\
\hline & & $0 \%$ & $0.1-9.9 \%$ & $10-19.9 \%$ & $20-29.9 \%$ & $30-39.9 \%$ & $40-49.9 \%$ & $>50 \%$ & Total & \\
\hline \multirow[t]{7}{*}{$\begin{array}{l}\text { Debt/Assets } \\
\text { in } 2006\end{array}$} & $0 \%$ & $44.2 \%$ & $29.2 \%$ & $10.6 \%$ & $7.1 \%$ & $1.8 \%$ & $1.8 \%$ & $5.3 \%$ & $100.0 \%$ & 113 \\
\hline & $0.1-9.9 \%$ & $13.6 \%$ & $35.6 \%$ & $26.5 \%$ & $13.6 \%$ & $6.0 \%$ & $2.2 \%$ & $2.5 \%$ & $100.0 \%$ & 317 \\
\hline & $10-19.9 \%$ & $6.6 \%$ & $21.4 \%$ & $27.6 \%$ & $27.9 \%$ & $7.9 \%$ & $4.5 \%$ & $4.1 \%$ & $100.0 \%$ & 290 \\
\hline & $20-29.9 \%$ & $1.1 \%$ & $17.3 \%$ & $17.6 \%$ & $27.1 \%$ & $22.9 \%$ & $7.4 \%$ & $6.7 \%$ & $100.0 \%$ & 284 \\
\hline & $30-39.9 \%$ & $1.9 \%$ & $4.3 \%$ & $11.6 \%$ & $29.5 \%$ & $26.1 \%$ & $14.0 \%$ & $12.6 \%$ & $100.0 \%$ & 207 \\
\hline & $40-49.9 \%$ & $0.9 \%$ & $3.7 \%$ & $10.2 \%$ & $18.5 \%$ & $30.6 \%$ & $13.9 \%$ & $22.2 \%$ & $100.0 \%$ & 108 \\
\hline & $>50 \%$ & $1.9 \%$ & $6.8 \%$ & $11.7 \%$ & $9.7 \%$ & $17.5 \%$ & $22.3 \%$ & $30.1 \%$ & $100.0 \%$ & 103 \\
\hline
\end{tabular}


Table 3:

Total Changes in Capital Structure vs Volatility of Capital Structures

Companies have been split into categories based on the overall change in their capital structure between 2006 and 2016. Companies which reduced their capital structures by $15 \%$ or more are in the first group, those which reduced by $5 \%$ to $15 \%$ are in the second group (b), those which reduced or increased by less than $5 \%$ are in the third group (c), those which increased by $5 \%$ to $15 \%$ are in the fourth group (d), and those which increased by more than $15 \%$ are in the final group. The companies are also grouped according to the standard deviation of their capital structures between 2006 and 2016, with companies split into quintiles with approximately equal numbers of companies in each quintile. The percentage of companies with a given change in capital structure and volatility is reported.

\begin{tabular}{lccccccc}
\hline \hline & & \multicolumn{7}{c}{ Volatility of Capital Structures } \\
& & Lowest & $\mathrm{m}$ & $\mathrm{n}$ & $\mathrm{o}$ & Highest & Total \\
\cline { 3 - 8 } & Reductions & $11.1 \%$ & $15.8 \%$ & $19.5 \%$ & $20.5 \%$ & $33.2 \%$ & $100.0 \%$ \\
Changes in & $\mathrm{b}$ & $17.6 \%$ & $28.9 \%$ & $14.6 \%$ & $21.8 \%$ & $17.2 \%$ & $100.0 \%$ \\
$\begin{array}{c}\text { Capital } \\
\text { Structures }\end{array}$ & $\mathrm{c}$ & $37.7 \%$ & $18.2 \%$ & $17.8 \%$ & $15.3 \%$ & $11.0 \%$ & $100.0 \%$ \\
& $\mathrm{~d}$ & $11.6 \%$ & $28.5 \%$ & $27.8 \%$ & $18.0 \%$ & $14.1 \%$ & $100.0 \%$ \\
& Increases & $4.6 \%$ & $7.6 \%$ & $21.1 \%$ & $29.5 \%$ & $37.1 \%$ & $100.0 \%$ \\
\hline \hline
\end{tabular}


Table 4

Changes in Capital Structure and Volatility of Capital Structures by Country

In Panel A, companies have been split into categories based on the overall change in their capital structure between 2006 and 2016. Companies which reduced their capital structures by $15 \%$ or more are in the first group, those which reduced by $5 \%$ to $15 \%$ are in the second group (b), those which reduced or increased by less than $5 \%$ are in the third group (c), those which increased by $5 \%$ to $15 \%$ are in the fourth group (d), and those which increased by more than $15 \%$ are in the final group. The percentage of companies in each country which have a given change in capital structure is then shown. In Panel B, companies are grouped according to the standard deviation of their capital structures between 2006 and 2016, with companies split into quintiles with approximately equal numbers of companies in each quintile. The percentage of companies in each country which have a given volatility in their capital structures is then shown.

\begin{tabular}{lccccccc}
\hline \hline & \multicolumn{7}{c}{ Panel A: Changes in Capital Structure } \\
\hline UK & Reductions & $\mathrm{b}$ & $\mathrm{c}$ & $\mathrm{d}$ & Increases & Total & Number \\
France & $13.2 \%$ & $15.8 \%$ & $36.3 \%$ & $18.1 \%$ & $16.6 \%$ & $100 \%$ & 463 \\
Germany & $9.8 \%$ & $16.9 \%$ & $38.9 \%$ & $22.6 \%$ & $11.8 \%$ & $100 \%$ & 296 \\
Italy & $15.9 \%$ & $19.1 \%$ & $30.7 \%$ & $20.2 \%$ & $14.1 \%$ & $100 \%$ & 277 \\
Greece & $9.4 \%$ & $22.5 \%$ & $23.2 \%$ & $25.4 \%$ & $19.6 \%$ & $100 \%$ & 138 \\
Spain & $16.0 \%$ & $10.9 \%$ & $24.4 \%$ & $15.1 \%$ & $33.6 \%$ & $100 \%$ & 119 \\
Ireland & $14.8 \%$ & $19.7 \%$ & $23.0 \%$ & $18.0 \%$ & $24.6 \%$ & $100 \%$ & 61 \\
Portugal & $21.1 \%$ & $13.2 \%$ & $50.0 \%$ & $13.2 \%$ & $2.6 \%$ & $100 \%$ & 38 \\
\hline & $23.3 \%$ & $6.7 \%$ & $33.3 \%$ & $26.7 \%$ & $10.0 \%$ & $100 \%$ & 30 \\
\hline \multicolumn{7}{c}{ Panel B: Volatility of Capital Structures } \\
\hline UK & Lowest & $\mathrm{m}$ & $\mathrm{n}$ & $\mathrm{o}$ & Highest & Total & Number \\
France & $17.9 \%$ & $15.1 \%$ & $21.2 \%$ & $22.7 \%$ & $23.1 \%$ & $100 \%$ & 463 \\
Germany & $22.3 \%$ & $26.7 \%$ & $24.0 \%$ & $15.2 \%$ & $11.8 \%$ & $100 \%$ & 296 \\
Italy & $21.3 \%$ & $23.1 \%$ & $17.3 \%$ & $17.0 \%$ & $21.3 \%$ & $100 \%$ & 277 \\
Greece & $17.4 \%$ & $20.3 \%$ & $21.7 \%$ & $25.4 \%$ & $15.2 \%$ & $100 \%$ & 138 \\
Spain & $22.7 \%$ & $16.8 \%$ & $16.0 \%$ & $26.1 \%$ & $18.5 \%$ & $100 \%$ & 119 \\
Ireland & $16.4 \%$ & $19.7 \%$ & $18.0 \%$ & $14.8 \%$ & $31.1 \%$ & $100 \%$ & 61 \\
Portugal & $26.3 \%$ & $13.2 \%$ & $13.2 \%$ & $13.2 \%$ & $34.2 \%$ & $100 \%$ & 38 \\
\hline \hline
\end{tabular}




\section{Table 5 \\ Firm-Specific Factors Explaining Changes in Capital Structure, and Volatility of Capital Structure}

In Panel A, companies have been split into categories based on the overall change in their debt/asset ratios between 2006 and 2016. Companies which reduced their capital structures by $15 \%$ or more are in the first group, those which reduced by $5 \%$ to $15 \%$ are in the second group (b), those which reduced or increased by less than $5 \%$ are in the third group (c), those which increased by $5 \%$ to $15 \%$ are in the fourth group (d), and those which increased by more than $15 \%$ are in the final group. In Panel B, companies are grouped according to the standard deviation of their debt/asset ratios between 2006 and 2016, with companies split into quintiles with approximately equal numbers of companies in each quintile. The average of variables, across companies within each category, is then reported. Small Size is a dummy variable for companies in the lowest two deciles when ranked according to average total assets between 2006 and 2016, similar to Leary (2009). Total Assets is the average assets of companies between 2006 and 2016. Change in Assets is calculated as the assets in 2016 minus assets in 2006, scaled by assets in 2006. Return on Assets is the average profit/assets ratio between 2006 and 2016. Revenue Growth is the average annual sales growth of companies, expressed in percentages, between 2006 and 2016. Variables are winsorised at the $1 \%$ and $99 \%$ levels. Dummy variables are created for firms in companies which are classified as operating in the following ICB industries: Industrials, Utilities or Technology. All data is obtained from Bloomberg. For Panel A the difference between the quintiles with the largest reductions and increases is calculated, and the significance of t-tests is reported. For Panel B the difference between the quintiles with the highest and lowest volatility is calculated, and the significance of t-tests is reported.

\begin{tabular}{|c|c|c|c|c|c|c|c|}
\hline \multicolumn{8}{|c|}{ Panel A: Change in Debt/Assets between 2006 and 2016} \\
\hline & $\begin{array}{l}\text { Largest } \\
\text { Reduction }\end{array}$ & $\mathrm{b}$ & $\mathrm{c}$ & d & $\begin{array}{l}\text { Largest } \\
\text { Increase }\end{array}$ & Diff & $\begin{array}{c}\text { Sig.of } \\
\text { Diff }\end{array}$ \\
\hline Small Size & 0.19 & 0.17 & 0.21 & 0.14 & 0.23 & 0.03 & \\
\hline Total Assets & $2,354.24$ & $4,699.07$ & $3,972.11$ & $7,691.15$ & $1,619.13$ & -735.11 & \\
\hline Change in Assets & 1.13 & 0.92 & 1.28 & 1.35 & 1.70 & 0.57 & $*$ \\
\hline Return on Assets & 2.66 & 3.01 & 2.05 & 2.90 & -0.51 & -3.17 & $* * *$ \\
\hline Revenue Growth & 15.42 & 11.15 & 14.44 & 9.83 & 19.05 & 3.63 & \\
\hline Dummy Industrials & 0.35 & 0.23 & 0.33 & 0.37 & 0.24 & -0.11 & $* *$ \\
\hline Dummy Utility & 0.01 & 0.03 & 0.04 & 0.06 & 0.02 & 0.01 & \\
\hline Dummy Technology & 0.07 & 0.13 & 0.14 & 0.11 & 0.14 & 0.07 & $* *$ \\
\hline \multicolumn{8}{|c|}{ Panel B: Volatility of Debt/Assets between 2006 and 2016} \\
\hline & Lowest & $\mathrm{m}$ & $\mathrm{n}$ & o & Highest & Diff & $\begin{array}{l}\text { Sig. of } \\
\text { Diff. }\end{array}$ \\
\hline Small Size & 0.22 & 0.11 & 0.19 & 0.18 & 0.25 & 0.03 & \\
\hline Total Assets & $5,473.89$ & $5,749.74$ & $4,204.95$ & $3,149.40$ & $2,561.33$ & -2912.56 & $* *$ \\
\hline Change in Assets & 1.13 & 1.07 & 1.19 & 1.39 & 1.64 & 0.50 & $* *$ \\
\hline Return on Assets & 2.42 & 3.12 & 3.33 & 2.30 & -1.00 & -3.42 & $* * *$ \\
\hline Revenue Growth & 9.75 & 11.02 & 10.28 & 15.70 & 22.58 & 12.83 & $* * *$ \\
\hline Dummy Industrials & 0.30 & 0.31 & 0.33 & 0.32 & 0.29 & -0.01 & \\
\hline Dummy Utility & 0.04 & 0.05 & 0.04 & 0.01 & 0.02 & -0.02 & \\
\hline Dummy Technology & 0.15 & 0.09 & 0.10 & 0.14 & 0.12 & -0.03 & \\
\hline
\end{tabular}




\section{Table 6 \\ Regressions Explaining Changes in Total Debt/Assets Ratio Between 2006 and 2016}

The dependent variable is the change in the company's total debt/assets ratio between 2006 and 2016. Small Size is a dummy variable for companies in the lowest two deciles when ranked according to average total assets between 2006 and 2016, similar to Leary (2009). Total Assets is the average assets of companies between 2006 and 2016. Change in Assets is calculated as the assets in 2016 minus assets in 2006, scaled by assets in 2006. Return on Assets is the average profit/assets ratio between 2006 and 2016. Revenue Growth is the average annual sales growth of companies, expressed in percentages, between 2006 and 2016. Variables are winsorised at the 1\% and $99 \%$ levels. Dummy variables are created for firms which are classified as operating in the following ICB industries: Industrials, Utilities or Technology. Dummy variables are also created for companies domiciled in France, Germany, or the PIIGS (Portugal, Ireland, Italy, Greece and Spain), with UK being the base group. All data is obtained from Bloomberg. Significance at $1 \%$ is denoted by $* * *, 5 \%$ by **, and $10 \%$ by $*$.

\begin{tabular}{|c|c|c|c|c|c|c|}
\hline & $(1)$ & (2) & (3) & (4) & $(5)$ & (6) \\
\hline Small Size & $\begin{array}{c}0.520 \\
(1.358)\end{array}$ & & & & & $\begin{array}{l}-1.826 \\
(1.483)\end{array}$ \\
\hline TotAssets & & $\begin{array}{l}-0.000 \\
(0.000)\end{array}$ & & & & $\begin{array}{c}0.000 \\
(0.000)\end{array}$ \\
\hline ChangeAssets & & $\begin{array}{c}0.391 \\
(0.281)\end{array}$ & & & & $\begin{array}{c}0.703 * * \\
(0.309)\end{array}$ \\
\hline ROA & & & $\begin{array}{c}-0.416 * * * \\
(0.093)\end{array}$ & & & $\begin{array}{c}-0.494 * * * \\
(0.100)\end{array}$ \\
\hline SalesGrowth & & & $\begin{array}{l}-0.005 \\
(0.019)\end{array}$ & & & $\begin{array}{l}-0.021 \\
(0.019)\end{array}$ \\
\hline Industrials & & & & $\begin{array}{l}-1.067 \\
(1.087)\end{array}$ & & $\begin{array}{c}0.181 \\
(1.077)\end{array}$ \\
\hline Utilities & & & & $\begin{array}{l}3.235^{*} \\
(1.796)\end{array}$ & & $\begin{array}{l}2.886^{*} \\
(1.745)\end{array}$ \\
\hline Technology & & & & $\begin{array}{c}2.232 \\
(1.579)\end{array}$ & & $\begin{array}{l}3.094^{*} \\
(1.638)\end{array}$ \\
\hline France & & & & & $\begin{array}{c}0.013 \\
(1.211)\end{array}$ & $\begin{array}{c}0.234 \\
(1.217)\end{array}$ \\
\hline Germany & & & & & $\begin{array}{c}-1.256 \\
(1.379)\end{array}$ & $\begin{array}{l}-0.660 \\
(1.386)\end{array}$ \\
\hline PIIGS & & & & & $\begin{array}{c}3.142 * * \\
(1.389)\end{array}$ & $\begin{array}{c}3.289 * * \\
(1.385)\end{array}$ \\
\hline Constant & $\begin{array}{c}1.664 * * * \\
(0.532)\end{array}$ & $\begin{array}{c}1.279 * * \\
(0.632)\end{array}$ & $\begin{array}{c}2.671 * * * \\
(0.657)\end{array}$ & $\begin{array}{c}1.715^{* *} \\
(0.709)\end{array}$ & $\begin{array}{c}1.152 \\
(0.872)\end{array}$ & $\begin{array}{c}1.118 \\
(1.227)\end{array}$ \\
\hline Observations & 1,422 & 1,422 & 1,404 & 1,422 & 1,422 & 1,404 \\
\hline R-squared & 0.000 & 0.003 & 0.026 & 0.004 & 0.008 & 0.043 \\
\hline
\end{tabular}


Table 7

Regressions Explaining Volatility of Total Debt/Assets Ratio

Between 2006 and 2016

The dependent variable is capital structure volatility, as measured by the standard deviation of a company's total debt/assets ratio between 2006 and 2016. Small Size is a dummy variable for companies in the lowest two deciles when ranked according to average total assets between 2006 and 2016, similar to Leary (2009). Total Assets is the average assets of companies between 2006 and 2016. Change in Assets is calculated as the assets in 2016 minus assets in 2006, scaled by assets in 2006. Return on Assets is the average profit/assets ratio between 2006 and 2016. Revenue Growth is the average annual sales growth of companies, expressed in percentages, between 2006 and 2016. Dummy variables are created for firms which are classified as operating in the following ICB industries: Industrials, Utilities or Technology. Dummy variables are also created for companies domiciled in France, Germany, or the PIIGS (Portugal, Ireland, Italy, Greece and Spain), with UK being the base group. All data is obtained from Bloomberg. Significance at $1 \%$ is denoted by ***, $5 \%$ by **, and $10 \%$ by $*$.

\begin{tabular}{|c|c|c|c|c|c|c|}
\hline & $(1)$ & $(2)$ & (3) & (4) & $(5)$ & $(6)$ \\
\hline Small Size & $\begin{array}{c}0.997 * * * \\
(0.380)\end{array}$ & & & & & $\begin{array}{c}0.137 \\
(0.380)\end{array}$ \\
\hline TotAssets & & $\begin{array}{c}-0.000^{* * * *} \\
(0.000)\end{array}$ & & & & $\begin{array}{c}-0.000^{* *} \\
(0.000)\end{array}$ \\
\hline ChangeAssets & & $\begin{array}{c}0.079 \\
(0.066)\end{array}$ & & & & $\begin{array}{l}0.159^{* * *} \\
(0.070)\end{array}$ \\
\hline ROA & & & $\begin{array}{c}-0.152 * * * \\
(0.027)\end{array}$ & & & $\begin{array}{c}-0.160 * * * \\
(0.029)\end{array}$ \\
\hline SalesGrowth & & & $\begin{array}{l}0.008^{*} \\
(0.004)\end{array}$ & & & $\begin{array}{c}0.004 \\
(0.005)\end{array}$ \\
\hline Industrials & & & & $\begin{array}{l}-0.388 \\
(0.270)\end{array}$ & & $\begin{array}{l}-0.137 \\
(0.256)\end{array}$ \\
\hline Utilities & & & & $\begin{array}{c}-1.302 * * \\
(0.554)\end{array}$ & & $\begin{array}{c}-1.182^{* *} \\
(0.491)\end{array}$ \\
\hline Technology & & & & $\begin{array}{l}-0.244 \\
(0.410)\end{array}$ & & $\begin{array}{l}-0.227 \\
(0.420)\end{array}$ \\
\hline France & & & & & $\begin{array}{c}-1.335^{* * *} \\
(0.319)\end{array}$ & $\begin{array}{c}-1.147 * * * \\
(0.316)\end{array}$ \\
\hline Germany & & & & & $\begin{array}{l}-0.575 \\
(0.354)\end{array}$ & $\begin{array}{l}-0.262 \\
(0.343)\end{array}$ \\
\hline PIIGS & & & & & $\begin{array}{c}0.027 \\
(0.340)\end{array}$ & $\begin{array}{c}0.057 \\
(0.330)\end{array}$ \\
\hline Constant & $\begin{array}{c}6.003 * * * \\
(0.127)\end{array}$ & $\begin{array}{c}6.207 * * * \\
(0.160)\end{array}$ & $\begin{array}{c}6.434 * * * \\
(0.169)\end{array}$ & $\begin{array}{c}6.386^{* * * *} \\
(0.178)\end{array}$ & $\begin{array}{c}6.576^{* * * *} \\
(0.223)\end{array}$ & $\begin{array}{c}6.746^{* * *} \\
(0.298)\end{array}$ \\
\hline Observations & 1,422 & 1,422 & 1,404 & 1,422 & 1,422 & 1,404 \\
\hline R-squared & 0.007 & 0.008 & 0.070 & 0.003 & 0.013 & 0.092 \\
\hline
\end{tabular}


Table 8

Final Debt Ratios decomposed into Initial Debt and Changes in Debt

Companies have been split into categories based on the overall change in their debt/asset ratios between 2006 and 2016 . Companies which reduced their capital structures by $15 \%$ or more are in the first group, those which reduced by $5 \%$ to $15 \%$ are in the second group (b), those which reduced or increased by less than $5 \%$ are in the third group (c), those which increased by 5\% to $15 \%$ are in the fourth group (d), and those which increased by more than $15 \%$ are in the final group. For each group, the origin of assets in 2016 is shown, by taking the value of debt, equity and other liabilities in 2006, and scaling them by the value of assets in 2016 . The change in debt, equity and other liabilities between 2006 and 2016 is also shown, scaled by the value of assets in 2016 . The change in debt is decomposed into debt flows, which is the sum of changes in debt shown on the cash flow statement from 2006 to 2016, and changes in debt which appear only on the balance sheet, which is defined as changes in the balance sheet value of debt minus the changes in debt shown on the cash flow statement. Each of these are also scaled by the value of assets in 2016 . The initial debt ratio of companies in 2006 can be calculated as debt in 2006, divided by the sum of debt, equity and other liabilities in 2006 . The final debt/assets ratio of companies in 2016 if there were zero debt flows, can be calculated as debt in 2006, plus the change in balance sheet only debt between 2006 and 2016, divided by total assets in 2016 . The final debt/assets ratio of companies in 2016 can be calculated as debt in 2006, plus the change in balance sheet only debt between 2006 and 2016, plus debt flows from 2006 to 2016 , divided by total assets in 2016.

\begin{tabular}{|c|c|c|c|c|c|c|c|c|c|c|}
\hline \multirow{3}{*}{$\begin{array}{c}\text { Change in } \\
\text { Debt/Assets } \\
\text { Ratio between } \\
2006 \text { and } 2016\end{array}$} & \multicolumn{7}{|c|}{ Origins of Assets in 2016 , by Asset Type } & \multicolumn{3}{|c|}{ Debt Ratios } \\
\hline & $\begin{array}{l}\text { Debt } \\
2006\end{array}$ & $\begin{array}{c}\text { Change in } \\
\text { Balance } \\
\text { Sheet } \\
\text { Only Debt } \\
\text { 2006-16 }\end{array}$ & $\begin{array}{c}\text { Debt } \\
\text { Flows } \\
2006-16\end{array}$ & $\begin{array}{l}\text { Equity } \\
2006\end{array}$ & $\begin{array}{l}\text { Change in } \\
\text { Equity } \\
2006-16\end{array}$ & $\begin{array}{c}\text { Other } \\
\text { Liabilities } \\
2006\end{array}$ & $\begin{array}{l}\text { Change in } \\
\text { Other } \\
\text { Liabilities } \\
\text { 2006-16 }\end{array}$ & $\begin{array}{c}\text { Initial } \\
\text { Debt/Assets }\end{array}$ & $\begin{array}{c}\text { Final Debt/Assets } \\
\text { if zero } \\
\text { Debt Flows }\end{array}$ & $\begin{array}{c}\text { Final Debt } \\
/ \\
\text { Assets }\end{array}$ \\
\hline & (1) & $(2)$ & (3) & (4) & $(5)$ & (6) & (7) & $\begin{array}{c}(1) \\
/ \\
(1+4+6)\end{array}$ & $\begin{array}{c}(1+2) \\
/ \\
(1+2+3+4+5+6+7)\end{array}$ & $\begin{array}{c}(1+2+3) \\
/ \\
(1+2+3+4+5+6+7)\end{array}$ \\
\hline Reductions & $42.6 \%$ & $-13.6 \%$ & $-13.7 \%$ & $30.1 \%$ & $19.4 \%$ & $31.3 \%$ & $3.8 \%$ & $42.9 \%$ & $29.1 \%$ & $15.4 \%$ \\
\hline $\mathrm{b}$ & $26.9 \%$ & $-5.0 \%$ & $-3.5 \%$ & $34.2 \%$ & $10.9 \%$ & $31.2 \%$ & $5.2 \%$ & $28.2 \%$ & $21.9 \%$ & $18.4 \%$ \\
\hline $\mathrm{c}$ & $12.1 \%$ & $1.4 \%$ & $3.2 \%$ & $40.9 \%$ & $7.8 \%$ & $28.0 \%$ & $6.7 \%$ & $16.7 \%$ & $13.5 \%$ & $16.7 \%$ \\
\hline $\mathrm{d}$ & $11.1 \%$ & $6.1 \%$ & $8.7 \%$ & $31.8 \%$ & $8.7 \%$ & $26.4 \%$ & $7.2 \%$ & $16.3 \%$ & $17.2 \%$ & $25.9 \%$ \\
\hline Increases & $25.2 \%$ & $6.0 \%$ & $16.4 \%$ & $45.0 \%$ & $-26.9 \%$ & $35.4 \%$ & $-1.1 \%$ & $15.7 \%$ & $31.2 \%$ & $47.5 \%$ \\
\hline
\end{tabular}


Table 9

Sources and Uses of Cash Flows for Companies,

grouped according to the average level of their Debt Flows

The components of the cash flow statement were obtained for each company, for each year from 2006 to 2016 , and scaled by total assets in each year, using data obtained from Bloomberg. Companies have been split into quintiles based on the average level of their debt flows, as a percentage of total assets, between 2006 and 2016 . The average of the other components of the cash flow statement are reported for each of these quintiles. Cash from Operating and Investing Activities (CFOI) is the sum of the first two major sections of the cash flow statement. Equity Payouts is the sum of dividends, equity repurchases, issues and other financing arrangements. Surplus or Deficit is the sum of CFOI, Changes in Cash Balances, and Equity Payouts. The difference between the quintiles with the largest inflows and outflows is then calculated, and the significance of t-tests is reported.

\begin{tabular}{|c|c|c|c|c|c|c|c|c|c|c|c|c|c|}
\hline $\begin{array}{c}\text { Average } \\
\text { Debt Flows } \\
\text { 2006-2016 }\end{array}$ & $\begin{array}{l}\text { Cash from } \\
\text { Operations }\end{array}$ & $\begin{array}{l}\text { Change in } \\
\text { Fixed and } \\
\text { Intangible } \\
\text { Assets }\end{array}$ & $\begin{array}{c}\text { Cash from } \\
\text { Acquisitions } \\
\text { and } \\
\text { Divestitures }\end{array}$ & $\begin{array}{c}\text { Other } \\
\text { Investments }\end{array}$ & $\begin{array}{c}\text { Cash from } \\
\text { Operating } \\
\text { and } \\
\text { Investing } \\
\text { Activities } \\
\end{array}$ & $\begin{array}{l}\text { Change } \\
\text { in Cash } \\
\text { Balances }\end{array}$ & Dividends & $\begin{array}{c}\text { Equity } \\
\text { Repurchases }\end{array}$ & $\begin{array}{l}\text { Equity } \\
\text { Issues }\end{array}$ & $\begin{array}{l}\text { Other } \\
\text { Finance }\end{array}$ & $\begin{array}{c}\text { Equity } \\
\text { Payouts }\end{array}$ & $\begin{array}{c}\text { Surplus or } \\
\text { Deficit }\end{array}$ & $\begin{array}{l}\text { Debt } \\
\text { Flow }\end{array}$ \\
\hline & (1) & (2) & (3) & (4) & $\begin{aligned} &(5) \\
&=(1+2 \\
&+3+4)\end{aligned}$ & (6) & (7) & (8) & (9) & (10) & $\begin{aligned} &(11) \\
&=(7+8+ \\
&9+10)\end{aligned}$ & $\begin{array}{c}(12) \\
=(5+6+10)\end{array}$ & (13) \\
\hline Largest Outflows & $6.0 \%$ & $-3.0 \%$ & $-0.1 \%$ & $-0.5 \%$ & $2.3 \%$ & $-0.1 \%$ & $-1.4 \%$ & $-0.4 \%$ & $1.9 \%$ & $0.1 \%$ & $0.1 \%$ & $2.4 \%$ & $-2.4 \%$ \\
\hline $\mathrm{p}$ & $6.2 \%$ & $-3.2 \%$ & $-0.3 \%$ & $-1.2 \%$ & $1.4 \%$ & $-0.7 \%$ & $-2.0 \%$ & $-0.4 \%$ & $2.1 \%$ & $0.0 \%$ & $-0.3 \%$ & $0.4 \%$ & $-0.4 \%$ \\
\hline $\mathrm{q}$ & $5.2 \%$ & $-3.6 \%$ & $-0.2 \%$ & $-1.5 \%$ & $-0.1 \%$ & $-0.5 \%$ & $-1.8 \%$ & $-0.4 \%$ & $2.6 \%$ & $-0.1 \%$ & $0.3 \%$ & $-0.3 \%$ & $0.3 \%$ \\
\hline $\mathrm{r}$ & $7.0 \%$ & $-4.3 \%$ & $-0.6 \%$ & $-1.5 \%$ & $0.6 \%$ & $-0.6 \%$ & $-2.0 \%$ & $-0.4 \%$ & $1.4 \%$ & $-0.3 \%$ & $-1.3 \%$ & $-1.2 \%$ & $1.2 \%$ \\
\hline Largest Inflows & $5.9 \%$ & $-5.4 \%$ & $-0.7 \%$ & $-2.7 \%$ & $-3.0 \%$ & $-0.7 \%$ & $-1.8 \%$ & $-0.7 \%$ & $2.9 \%$ & $-0.2 \%$ & $0.2 \%$ & $-3.5 \%$ & $3.5 \%$ \\
\hline Difference & $-0.1 \%$ & $-2.4 \% * * *$ & $-0.6 \% * * *$ & $-2.2 \% * * *$ & $-5.3 \% * * *$ & $-0.6 \% * * *$ & $-0.3 \% *$ & $-0.3 \% * *$ & $1.0 \% * *$ & $-0.3 \% *$ & $0.1 \%$ & $-5.9 \% * * *$ & $5.9 \% * * *$ \\
\hline
\end{tabular}


Table 10

Standard Deviation of Sources and Uses of Cash Flows for Companies,

grouped according to the Standard Deviation of their Debt Flows

The components of the cash flow statement were obtained for each company, for each year from 2006 to 2016 , and scaled by total assets in each year, using data obtained from Bloomberg. Companies have been split into quintiles based on the standard deviation of their debt flows, as a percentage of total assets, between 2006 and 2016 . The standard deviation of the other components of the cash flow statement are reported for each of these quintiles. Cash from Operating and Investing Activities (CFOI) is the sum of the first two major sections of the cash flow statement. Equity Payouts is the sum of dividends, equity repurchases, issues and other financing arrangements. Surplus or Deficit is the sum of CFOI, Changes in Cash Balances, and Equity Payouts. The difference between the quintiles with the highest and lowest standard deviations is then calculated, and the significance of t-tests is reported.

\begin{tabular}{|c|c|c|c|c|c|c|c|c|c|c|c|c|c|}
\hline $\begin{array}{l}\text { Standard Deviation } \\
\text { of Debt Flows } \\
2006-2016\end{array}$ & $\begin{array}{l}\text { Cash from } \\
\text { Operations }\end{array}$ & $\begin{array}{l}\text { Change in } \\
\text { Fixed and } \\
\text { Intangible } \\
\text { Assets }\end{array}$ & $\begin{array}{c}\text { Cash from } \\
\text { Acquisitions } \\
\text { and } \\
\text { Divestitures }\end{array}$ & $\begin{array}{c}\text { Other } \\
\text { Investments }\end{array}$ & $\begin{array}{c}\text { Cash } \\
\text { from } \\
\text { Operating } \\
\text { and } \\
\text { Investing } \\
\text { Activities } \\
\end{array}$ & $\begin{array}{l}\text { Change } \\
\text { in Cash } \\
\text { Balances }\end{array}$ & Dividends & $\begin{array}{c}\text { Equity } \\
\text { Repurchases }\end{array}$ & $\begin{array}{l}\text { Equity } \\
\text { Issues }\end{array}$ & $\begin{array}{l}\text { Other } \\
\text { Finance }\end{array}$ & $\begin{array}{c}\text { Equity } \\
\text { Payouts }\end{array}$ & $\begin{array}{c}\text { Surplus or } \\
\text { Deficit }\end{array}$ & $\begin{array}{l}\text { Debt } \\
\text { Flow }\end{array}$ \\
\hline & $(1)$ & $(2)$ & (3) & (4) & (5) & (6) & $(7)$ & $(8)$ & (9) & $(10)$ & (11) & (12) & (13) \\
\hline Lowest & $6.1 \%$ & $2.0 \%$ & $1.1 \%$ & $4.7 \%$ & $7.9 \%$ & $8.3 \%$ & $1.4 \%$ & $0.6 \%$ & $4.1 \%$ & $2.1 \%$ & $6.3 \%$ & $1.1 \%$ & $1.1 \%$ \\
\hline 2 & $4.2 \%$ & $2.2 \%$ & $1.3 \%$ & $3.0 \%$ & $6.0 \%$ & $4.8 \%$ & $0.9 \%$ & $0.6 \%$ & $1.9 \%$ & $2.0 \%$ & $3.7 \%$ & $3.1 \%$ & $3.1 \%$ \\
\hline 3 & $4.7 \%$ & $2.5 \%$ & $1.5 \%$ & $4.1 \%$ & $7.4 \%$ & $5.5 \%$ & $1.2 \%$ & $0.7 \%$ & $2.5 \%$ & $2.5 \%$ & $4.9 \%$ & $4.7 \%$ & $4.7 \%$ \\
\hline 4 & $5.7 \%$ & $2.9 \%$ & $1.7 \%$ & $5.2 \%$ & $8.7 \%$ & $6.4 \%$ & $1.2 \%$ & $0.9 \%$ & $3.4 \%$ & $2.3 \%$ & $5.6 \%$ & $6.6 \%$ & $6.6 \%$ \\
\hline Highest & $7.9 \%$ & $4.5 \%$ & $2.1 \%$ & $7.9 \%$ & $13.2 \%$ & $8.3 \%$ & $1.2 \%$ & $1.1 \%$ & $6.2 \%$ & $3.2 \%$ & $8.9 \%$ & $11.7 \%$ & $11.7 \%$ \\
\hline Difference & $1.9 \% * * *$ & $2.5 \% * * *$ & $1.0 \% * * *$ & $3.2 \% * * *$ & $5.3 \% * * *$ & $0.0 \%$ & $-0.2 \%$ & $0.5 \% * * *$ & $2.1 \% * * *$ & $1.1 \% * * *$ & $2.7 \% * * *$ & $10.6 \% * * *$ & $10.6 \% * * *$ \\
\hline
\end{tabular}


Table 11

\section{Responsiveness of Debt Flows, Equity Payouts and Changes in Cash Balance to Cash Flow from Operating and Investing Activities, by Debt Volatility Quintiles}

The Debt Flows, Equity Payouts, and Changes in Cash Balances of each company, in each year, are regressed against the Cash from Operating and Investing Activities (CFOI) of that company, in that year. Debt Flows, Equity Payouts and Changes in Cash Balances are all multiplied by -1 , to make the betas positive and more intuitive, with debt payouts, equity payouts, and increases in cash balances now appearing as being positive. All variables are scaled by total assets. Dummy variables are included for companies based on the standard deviation of their debt flows between 2006 and 2016. DummySDDebt5 are those companies with the highest volatility in their debt flows, DummySDDebt4 have the next highest volatility etc. These dummy variables are also interacted with CFOI. SmallSizeLag is a dummy variable for companies which had were in the lowest two deciles when ranked by total assets in the previous year. HighDebtLag is a dummy variable for companies which were in the highest two deciles when ranked by debt/assets in the previous year. LowDebtLag is a dummy variable for companies which were in the lowest two deciles when ranked by debt/assets in the previous year. NoDividendLag is a dummy variable for companies which did not pay a dividend in the previous year. NoRepurchasesLag is a dummy variable for companies which did not make repurchases in the previous year. Significance at $1 \%$ is denoted by $* * *, 5 \%$ by $* *$, and $10 \%$ by *.

\begin{tabular}{|c|c|c|c|}
\hline & $\begin{array}{c}(1) \\
\text { Debt } \\
\text { Flows } \\
\end{array}$ & $\begin{array}{c}\text { (2) } \\
\text { Equity } \\
\text { Payouts } \\
\end{array}$ & $\begin{array}{c}(3) \\
\text { Change in } \\
\text { Cash Balances } \\
\end{array}$ \\
\hline CFOI & $\begin{array}{c}0.037 * * * \\
(0.003)\end{array}$ & $\begin{array}{c}0.517 * * * \\
(0.033)\end{array}$ & $\begin{array}{c}0.446^{* * * *} \\
(0.034)\end{array}$ \\
\hline CFOI*DummySDDebt 2 & $\begin{array}{c}0.109 * * * \\
(0.012)\end{array}$ & $\begin{array}{l}-0.086^{*} \\
(0.047)\end{array}$ & $\begin{array}{l}-0.023 \\
(0.048)\end{array}$ \\
\hline CFOI*DummySDDebt3 & $\begin{array}{c}0.173 * * * \\
(0.014)\end{array}$ & $\begin{array}{l}-0.061 \\
(0.046)\end{array}$ & $\begin{array}{c}-0.112 * * \\
(0.045)\end{array}$ \\
\hline CFOI* DummySDDebt4 & $\begin{array}{c}0.248 * * * \\
(0.016)\end{array}$ & $\begin{array}{c}-0.109 * * \\
(0.044)\end{array}$ & $\begin{array}{c}-0.140 * * * \\
(0.042)\end{array}$ \\
\hline CFOI* DummySDDebt5 & $\begin{array}{c}0.371 * * * \\
(0.023)\end{array}$ & $\begin{array}{c}-0.171 * * * \\
(0.042)\end{array}$ & $\begin{array}{c}-0.200 * * * \\
(0.043)\end{array}$ \\
\hline DummySDDebt 2 & $\begin{array}{c}-0.006 * * * \\
(0.001)\end{array}$ & $\begin{array}{c}0.007 * * * \\
(0.002)\end{array}$ & $\begin{array}{l}-0.001 \\
(0.002)\end{array}$ \\
\hline DummySDDebt3 & $\begin{array}{c}-0.009 * * * \\
(0.001)\end{array}$ & $\begin{array}{c}0.011 * * * \\
(0.002)\end{array}$ & $\begin{array}{l}-0.002 \\
(0.002)\end{array}$ \\
\hline DummySDDebt4 & $\begin{array}{c}-0.010 * * * \\
(0.001)\end{array}$ & $\begin{array}{c}0.007 * * * \\
(0.002)\end{array}$ & $\begin{array}{c}0.003 \\
(0.002)\end{array}$ \\
\hline DummySDDebt5 & $\begin{array}{c}-0.009 * * * \\
(0.002)\end{array}$ & $\begin{array}{c}0.007 * * \\
(0.003)\end{array}$ & $\begin{array}{c}0.002 \\
(0.003)\end{array}$ \\
\hline SmallSizeLag & $\begin{array}{c}-0.004 * * * \\
(0.001)\end{array}$ & $\begin{array}{c}0.005 * * * \\
(0.001)\end{array}$ & $\begin{array}{l}-0.000 \\
(0.001)\end{array}$ \\
\hline HighDebtLag & $\begin{array}{c}0.010 * * * \\
(0.001)\end{array}$ & $\begin{array}{c}-0.008 * * * \\
(0.002)\end{array}$ & $\begin{array}{l}-0.002^{*} \\
(0.001)\end{array}$ \\
\hline LowDebtLag & $\begin{array}{c}-0.005^{* * * *} \\
(0.001)\end{array}$ & $\begin{array}{c}0.005 * * \\
(0.002)\end{array}$ & $\begin{array}{l}-0.001 \\
(0.002)\end{array}$ \\
\hline NoDividendLag & $\begin{array}{c}0.020 * * * \\
(0.001)\end{array}$ & $\begin{array}{c}-0.034 * * * \\
(0.002)\end{array}$ & $\begin{array}{c}0.014 * * * \\
(0.002)\end{array}$ \\
\hline NoRepurchasesLag & $\begin{array}{c}0.006^{* * *} \\
(0.001)\end{array}$ & $\begin{array}{c}-0.013 * * * \\
(0.001)\end{array}$ & $\begin{array}{c}0.008 * * * \\
(0.001)\end{array}$ \\
\hline Constant & $\begin{array}{c}-0.007 * * * \\
(0.001)\end{array}$ & $\begin{array}{c}0.016 * * * \\
(0.002)\end{array}$ & $\begin{array}{c}-0.008 * * * \\
(0.002)\end{array}$ \\
\hline $\begin{array}{l}\text { Observations } \\
\text { R-squared }\end{array}$ & $\begin{array}{c}14,220 \\
0.283\end{array}$ & $\begin{array}{c}14,220 \\
0.347\end{array}$ & $\begin{array}{c}14,220 \\
0.209\end{array}$ \\
\hline
\end{tabular}


Table 12

Decomposition of Variance in Changes in Debt

into Variance and Covariances of other Cash Flow Components

Companies have been split into quintiles based on the variance of their debt flows, as a percentage of total assets, between 2006 and 2016 . The variance and covariances of cash flow variables for each company between 2006 and 2016 are also calculated. Var(dDebt) is the variance of the flows of debt, Var(CFOI) is the variance of Cash from Operating and Investing activities, Var(dCash) is the variance of the change in cash holdings, and Var(EqPay) is the variance of equity pay-outs. Cov(CFOI, dCash) is the covariance of CFOI and cash holdings, Cov(CFOI, EqPay) is the covariance of CFOI and equity payouts, and Cov(dCash, EqPay) is the covariance of cash holdings and equity payouts. The average variance and covariance of each component for companies within each quintile is then calculated. The difference between the quintiles with the highest and lowest variance in debt flows is then calculated, and the significance of t-tests is reported.

\begin{tabular}{|c|c|c|c|c|c|c|c|c|}
\hline $\begin{array}{c}\text { Variance } \\
\text { of Debt Flows } \\
2006-2016\end{array}$ & $\operatorname{Var}(\mathrm{CFOI})$ & Var(EqPay) & Var(dCash) & $2 * \operatorname{Cov}(\mathrm{CFOI}, \mathrm{EqPay})$ & $2 * \operatorname{Cov}(\mathrm{CFOI}, \mathrm{dCash})$ & $2 * \operatorname{Cov}($ EqPay, dCash $)$ & Sum & $\operatorname{Var}(\mathrm{dDebt})$ \\
\hline & (1) & (2) & (3) & (4) & $(5)$ & (6) & $\begin{array}{l}=(1+2+3 \\
+4+5+6)\end{array}$ & \\
\hline Lowest & $1.0 \%$ & $0.9 \%$ & $1.3 \%$ & $-0.6 \%$ & $-1.4 \%$ & $-1.2 \%$ & $0.0 \%$ & $0.0 \%$ \\
\hline 2 & $0.5 \%$ & $0.3 \%$ & $0.4 \%$ & $-0.3 \%$ & $-0.5 \%$ & $-0.2 \%$ & $0.1 \%$ & $0.1 \%$ \\
\hline 3 & $0.7 \%$ & $0.5 \%$ & $0.5 \%$ & $-0.5 \%$ & $-0.6 \%$ & $-0.4 \%$ & $0.2 \%$ & $0.2 \%$ \\
\hline 4 & $0.9 \%$ & $0.6 \%$ & $0.7 \%$ & $-0.4 \%$ & $-0.7 \%$ & $-0.6 \%$ & $0.4 \%$ & $0.4 \%$ \\
\hline Highest & $2.2 \%$ & $1.3 \%$ & $1.1 \%$ & $-1.0 \%$ & $-1.1 \%$ & $-1.0 \%$ & $1.5 \%$ & $1.5 \%$ \\
\hline Difference & $1.1 \% * * *$ & $0.4 \% * *$ & $-0.2 \%$ & $-0.3 \% * *$ & $0.3 \%$ & $0.3 \%$ & $1.5 \% * * *$ & $1.5 \% * * *$ \\
\hline
\end{tabular}

